\title{
A preliminary survey on nest cavity use by Siberian flying squirrels, Pteromys volans orii, in forests of Hokkaido Island, Japan
}

\author{
Nami Kadoya, Kazunobu Iguchi, Masaki Matsui, Takumi Okahira, Ami Kato, \\ Tatsuo Oshida \& Yoshihiro Hayashi
}

\begin{abstract}
Pteromys volans orii, which is an endemic subspecies to Hokkaido Island, Japan, is arboreal and usually nests in cavities in trunks. To broadly understand what nest cavity is selected by $P$. volans orii in mountainous areas, we preliminary surveyed cavity resources in natural forests of Hokkaido. All nest cavities were on live-trees. Most of them were naturally formed after branches fall from the tree. These findings seem to be specific to Hokkaido population. Longest diameter of nest cavities was significantly shorter than that of unused cavities. This suggests that $P$. volans orii may select cavities with smaller entrances to avoid predators. The nest tree species most frequently used by this subspecies was Abies sachalinensis, which is most dominant in mountainous forests of Hokkaido. A. sachalinensis would provide abundant nest resources for $P$. volans orii.
\end{abstract}

KEY WORDS: Abies sachalinensis, Acer mono, arboreal mammals, sub-arctic mixed forests.

Nami Kadoya, Ami Kato, and Tatsuo Oshida* [oshidata@obihiro.ac.jp], Laboratory of Wildlife Ecology, Obihiro University of Agriculture and Veterinary Medicine, Obihiro 080-8555, Japan; Kazunobu Iguchi, Masaki Matsui, and Takumi Okahira, University Forest in Hokkaido, The University of Tokyo, Yamabe, Furano 079-1561, Japan; Yoshihiro Hayashi, Faculty of Agriculture, The University of Tokyo, Yayoi, Bunkyo-ku 113-8657, Japan

*Correspondence author: Tatsuo Oshida

\section{Предварительное исследование гнездовых полостей, используемых летягой, Pteromys volans orii, в лесах острова Хоккайдо, Япония}

\begin{abstract}
Н. Кадоя, К. Игучи, М. Матсуи, Т. Окахира, А. Като, Т. Ошида \& Й. Хаяши
PЕЗЮМЕ. Pteromys volans orii, эндемичный подвид для острова Хоккайдо, Япония, древесное животное, обычно делающее гнезда в полостях стволов деревьев. Для того чтобы понять, какие полости выбираются P. volans orii в горных районах, мы провели предварительное исследование ресурсов полостей в естественных лесах Хоккайдо. Все гнездовые полости были обнаружены в живых деревьях. Большинство из них образовалось после отпадения ветвей. Эти особенности характерны для популяции Хоккайдо. Наибольший диаметр гнездовых полостей был значимо меньше, чем незаселенных полостей. Это позволяет предположить, что P. volans orii может выбирать полости с небольшими входными отверстиями для защиты от хищников. Дерево, которое наиболее часто использовалось этим подвидом для гнезд - Abies sachalinensis, доминирующий вид горных лесов Хоккайдо. A. sachalinensis предоставляет обильные гнездовые ресурсы для P. volans orii.
\end{abstract}

КЛЮЧЕВЫЕ СЛОВА: Abies sachalinensis, Acer mоno, древесные млекопитающие, субарктические смешанные леса.

\section{Introduction}

To understand ecological requirements of arboreal mammals, it is important to identify nest resources. These include tree species within which an arboreal animal nests, size of nests required, and origin of the nests, whether naturally formed or constructed by arboreal mammal or by another species. In the forests of North America, northern flying squirrels (Glaucomys sabrinus) prefer larger trees for nests (Cotton \& Parker, 2000; Menzel et al., 2004; Meyer et al., 2005), as does the southern flying squirrel, G. volans (Holloway \& Malcolm, 2007). In central Ontario, Canada, G. volans uses hollows within American beech (Fagus grandifolia) for nesting (Holloway \& Malcolm, 2007). Glaucomys sabrinus selectively uses trembling aspen (Populus tremuloides), white birch (Betula papyrifera), and yellow birch (B. alleghaniensis) in central Ontario (Holloway \& Malcolm, 2007) and P. tremuloides in British Columbia, Canada (Martin et al., 2004).

We undertook a preliminary assessment of the nest requirements of the Siberian flying squirrel Pteromys 


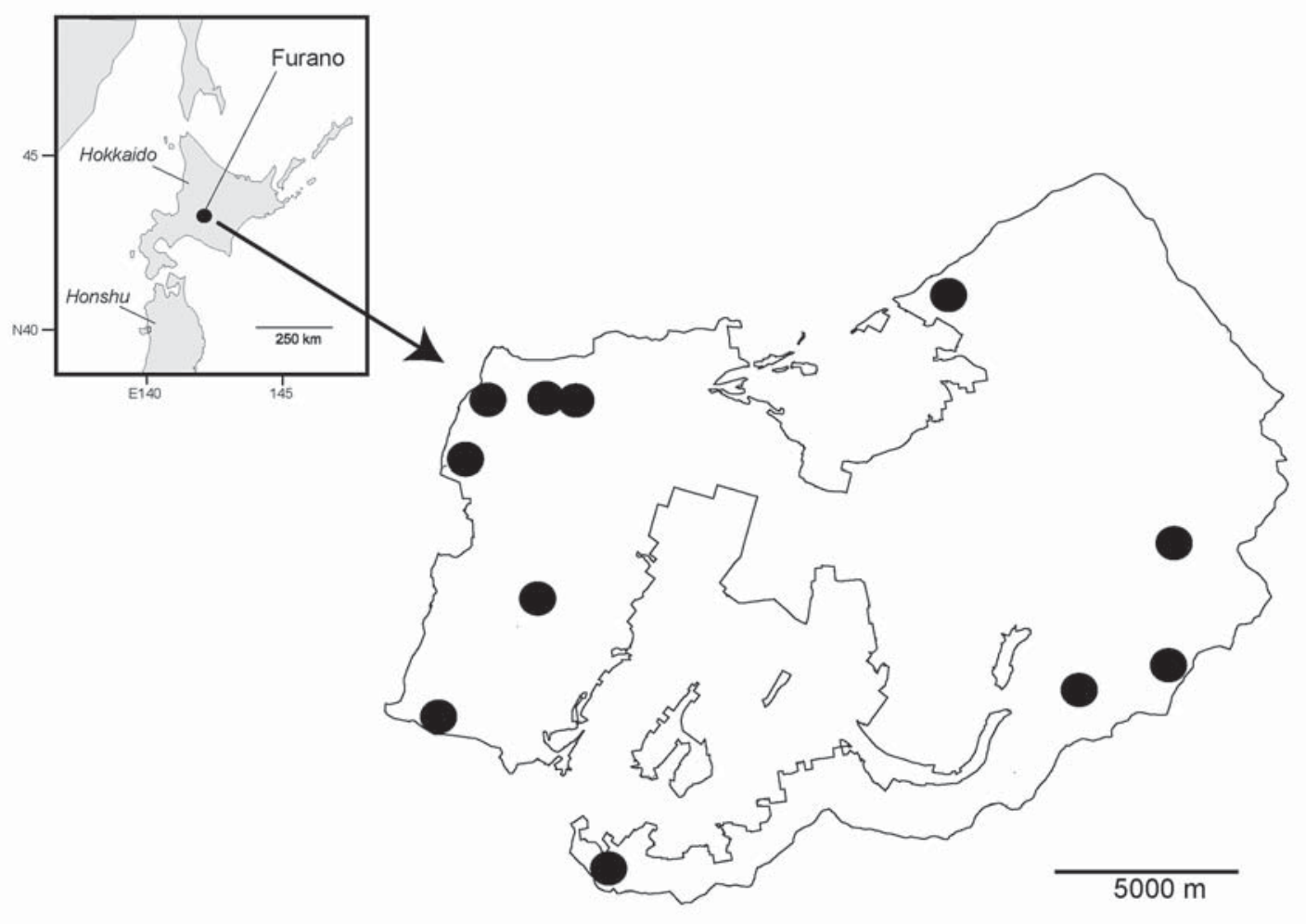

Figure 1. Map of study area (University Forest in Hokkaido, The University of Tokyo in Furano, Japan) covered with the sub-arctic mixed forest, showing 11 areas (closed circles) surveyed for trees with cavities nested in or not used by Pteromys volans orii.

volans orii on Hokkaido Island, Japan. Pteromys volans is widely distributed from northern Finland east to Chukotka of Russia; south to the eastern Baltic shore and across the southern Ural Mountains and Altai Mountains of Russia to Mongolia, northern China, Korea, Sakhalin Island of Russia, and Hokkaido Island of Japan (Nowak, 1991; Wilson \& Reeder, 2005). This species is arboreal and inhabits the boreal evergreen forests of the Eurasian Continent (e.g., Nowak, 1991). Pteromys volans orii, a subspecies endemic to Hokkaido Island, is common from lowland to mountainous areas (Abe et al., 2005). The vegetation of Hokkaido's natural forests mainly consists of Abies sachalinensis, Picea jezoensis, Quercus mongolica, Betula spp., and Tilia japonica (Tatewaki, 1958; Horikawa, 1972; Okit$\mathrm{su}, 2002)$. This is quite different from forests of northern Eurasia where $P$. volans is extensively distributed. Confined to Hokkaido Island, southern parts of Sakhalin Island, and Kuril Islands (Satake, 1989), Abies sachalinensis is the most abundant tree in Hokkaido's natural forests. Unlike the forests of northern Eurasia, several kinds of hardwood trees account for $60 \%$ of vegetation in Hokkaido forests (Okitsu, 2002). In this unique sub-arctic mixed forest of Hokkaido, $P$. volans orii may more frequently nest in abundant trees such as Abies sachalinensis and hardwoods. Similar to Gla- comys species (Cotton \& Parker, 2000; Holloway \& Malcolm, 2007), P. volans orii may prefer nesting in larger trees. To examine these conjectures, we surveyed the forests of Hokkaido for nest cavities and use by $P$. volans orii.

\section{Study Area}

The study was conducted in the University Forest in Hokkaido, The University of Tokyo, Furano, Japan $\left(43^{\circ} 10^{\prime}-20^{\prime} \mathrm{N}, 142^{\circ} 20^{\prime}-40^{\prime} \mathrm{E}\right.$; Fig. 1). This forest has an area of 22,849 ha and is covered with natural subarctic mixed-forests. In this forest, the dominant standing crop, which occupies more than $5 \%$ of the total, is Abies sachalinensis (44.75\%), Tilia japonica (8.96\%), Acer mono (7.98\%), and Picea jezoensis (7.84\%) (Yamamoto et al., 1995).

\section{Methods}

From May to October 2007, we randomly surveyed for cavity trees and cavities in trees along paths in 11 different areas of the forest (Fig. 1). We concentrated on locating cavities $<4 \mathrm{~m}$ above the ground because it was difficult and dangerous to check for cavities located higher up the trees. Cavity trees were described by 
Table 1. Mean measurements (SD in parentheses) of cavity trees and nearest trees with diameter at breast height (DBH) $>20 \mathrm{~cm}$ in the sub-arctic mixed forests of Hokkaido, Japan.

\begin{tabular}{|l|l|l|l|l|}
\hline & Trees $(\mathrm{N})$ & Height $(\mathrm{m})$ & $\mathrm{DBH}(\mathrm{cm})$ & $\mathrm{DCH}(\mathrm{cm})$ \\
\hline Cavity trees & & & & \\
$\quad$ Used & 12 & $21.44(4.53)$ & $50.80(7.94)$ & $43.65(8.50)$ \\
$\quad$ Unused & 29 & $17.54(8.88)$ & $44.55(20.93)$ & $40.12(16.34)$ \\
$\quad$ Total & 41 & $18.68(8.00)$ & $46.38(18.23)$ & $41.15(14.47)$ \\
& & & & \\
Trees with DBH > 20cm & 12 & $19.03(5.58)$ & $36.12(16.04)$ & - \\
$\quad$ Nearest to used cavity tree & 29 & $19.50(6.46)$ & $39.50(19.01)$ & - \\
$\quad$ Nearest to unused cavity tree & 41 & $19.36(6.15)$ & $38.57(18.05)$ & - \\
$\quad$ Total & & & & \\
\hline
\end{tabular}

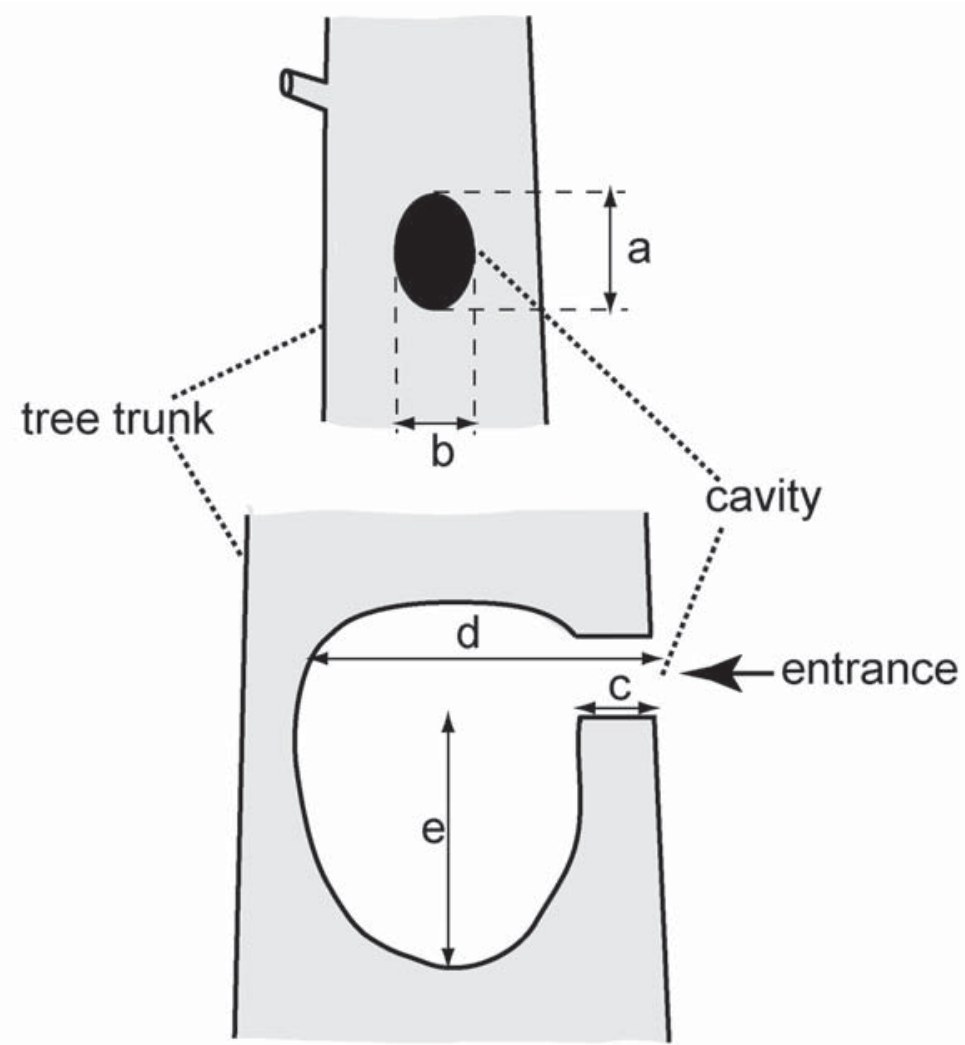

Figure 2. Measurements used to describe tree cavities used or not used as nests by Pteromys volans orii: $\mathrm{a}$ - longest diameter, $\mathrm{b}$ - shortest diameter, $\mathrm{c}$ - thickness of entrance margin, $\mathrm{d}$ - length from entrance to inner wall, e depth. Measurements follow Masuda (2003) and Meyer et al. (2005).

species, height, diameter at breast height (DBH), diameter at cavity height (DCH) (Tab. 1), and type (living or snag). To test if cavities were in the larger trees in the study area, we followed Meyer et al. (2005) by recording species, height, $\mathrm{DBH}$, and type for the nearest large tree $(>20.0 \mathrm{~cm} \mathrm{DBH})$. We also described each cavity in tree (Tab. 2, Fig. 2), noting how the cavities were made and whether they were used by $P$. volans orii. We used a Mann-Whitney $U$-test to compare cavity trees to the nearest tree and to compare cavities used by flying squirrels with unused cavities.

\section{Results and discussion}

We found a total of 41 cavity trees of which 12 were used by $P$. volans orii. Each tree had one cavity. All 
Table 2. Mean measurements (SD in parentheses) of cavities in trees of the sub-arctic mixed forests of Hokkaido, Japan, used $(\mathrm{N}=12)$ as nests or unused $(\mathrm{N}=29)$ by Pteromys volans orii.

\begin{tabular}{|l|l|l|}
\hline Variable & Used & Unused \\
\hline Height above ground $(\mathrm{m})$ & $2.31(1.08)$ & $1.81(1.13)$ \\
Longest diameter $(\mathrm{mm})$ & $53.03(26.22)$ & $87.03(40.70)$ \\
Shortest diameter $(\mathrm{mm})$ & $26.36(9.27)$ & $36.08(16.58)$ \\
Thickness of entrance margin (cm) & $6.94(2.17)$ & $5.73(2.57)$ \\
Length from entrance to inner wall (cm) & $22.34(7.01)$ & $17.25(6.90)$ \\
Depth (cm) & $36.17(34.70)$ & $21.08(28.80)$ \\
\hline
\end{tabular}

* described in Fig. 2.

Table 3. Cavity trees nested in or unused by Pteromys volans orii in the sub-arctic mixed forests of Hokkaido, Japan.

\begin{tabular}{|l|l|l|l|}
\hline \multirow{4}{*}{ Species } & \multicolumn{3}{l|}{ Trees with cavities' (N) $^{\prime}$} \\
\cline { 2 - 4 } & Nest $^{2}$ & Unused & Total \\
\hline Conifers & & & \\
Abies sachalinensis & 7 & 9 & 16 \\
Picea jezoensis & - & 1 & 1 \\
Hardoods & & & \\
Acer amoenum & - & 2 & 2 \\
Acer mono & 3 & 6 & 9 \\
Alnus hirsuta & - & 1 & 1 \\
Phellodendron amurense & - & 2 & 2 \\
Populus tremula & 1 & - & 1 \\
Prunus ssiori & - & 1 & 1 \\
Quercus mongolica & - & 3 & 3 \\
Tilia japonica & 1 & 2 & 3 \\
Unknown & - & 2 & 2 \\
Total & 12 & 29 & 41 \\
\hline
\end{tabular}

${ }^{1}$ Number of cavities found $<4 \mathrm{~m}$ above the ground.

${ }^{2}$ Presence of flying squirrel, hairs, or dropping indicated cavity was used as a nest.

nest cavities were on live-trees. Ten nest cavities were naturally formed after branches fall from the tree. One nest cavity was made by a woodpecker. One crack-like nest cavity was the result of freezing during winter.

Measurements of trees and cavities are shown in Tables 1 and 2, respectively. The DBH of cavity trees was significantly larger than that of nearest large trees $(z=-2.2165$, d.f. $=1, P<0.05)$, but tree height was not $(z=0.4840$, d.f. $=1, P>0.5)$ (Tab. 2). Trees with nest cavities did not differ from trees with unused cavities in $\mathrm{DBH}$ $(z=1.7621$, d.f. $=1, P>0.05)$ and height $(z=1.3467, d . f .=1$, $P>0.05)$. Nest cavity trees had significantly larger $\mathrm{DBH}$ than nearest large trees $(z=2.3382$, d. $f .=1, P<0.05)$, but tree height did not differ $(z=0.9241$, d. $f .=1, P>0.1)$. Longest diameter of nest cavities was significantly shorter than that of unused cavities $(z=2.6273, d . f$. $=1, P<0.05)$. 
The nest tree species most frequently used by $P$. volans orii was Abies sachalinensis (Tab. 3). This finding corresponded to previous studies (Nakano et al., 1991; Masuda, 2003) conducted in different areas of Hokkaido during only winter. The fact that Abies sachalinensis was the most dominant tree species probably contributed to its importance as a nest tree, although it was difficult to perform the statistic analysis on the numbers of cavities correlated with tree species dominance, due to insufficient data in number of cavities. Moreover, Acer mono was also frequently used (Tab. 3). In Finland and Russia, $P$. volans mainly used cavities in aspens (Populus tremula) (Hanski et al., 2000b; Airapetyants \& Fokin, 2003). In Ontario, Canada, hardwood trees such as Fagus grandifolia and Populus tremuloides were frequently used by $G$. volans and G. sabrinus (Holloway \& Malcolm, 2007). Compared to conifers, hardwoods have a decay processes conclusive to natural cavity formation and woodpecker excavation (McComb \& Lindenmayer, 1999). In the subarctic mixed forests of Hokkaido, $P$. volans orii used cavities in hardwood trees such as Acer mono. Further studies should test this is an actual preference or is merely correlated to cavity tree availability.

The DBH of trees with cavities and nests of $P$. volans orii was significantly larger than that of the nearest large trees $(P<0.05)$. Glaucomys sabrinus preferentially uses larger nest trees (Cotton \& Parker, 2000; Bakker \& Hastings, 2002; Menzel et al., 2004; Meyer et al., 2005), as does G. volans (Meyer et al., 2005; Holloway \& Malcolm, 2007). Therefore, large trees are important resources for arboreal small mammals in the sub-boreal regions.

Glaucomys prefers snags to live trees (Taulman, 1999; Meyer et al., 2005), but we found that $P$. volans orii nested in only live trees. In Ontario, Canada, Glaucomys (especially G. volans) uses fewer snags and more live trees than reported for other regions (Holloway \& Malcolm, 2007). As older and larger trees have decay (Parks \& Shaw, 1996), older and larger snags would provide many cavities that could make suitable nests. Snags, however, may not be always important for flying squirrels.

Studies on Pteromys volans in Russia, Finland, and Japan suggest that it tends to use cavities made by woodpeckers (Hanski et al., 2000a; Hanski et al., 2000b; Airapetyants \& Fokin, 2003; Masuda, 2003). This also seems to be the case for Glaucomys flying squirrels (Holloway \& Malcolm, 2007). In contrast, we found only one cavity used by $P$. volans orii that was made by a woodpecker. That $P$. volans orii selected cavities formed naturally is supported by a study in the natural forest of northern Hokkaido during winter (Nakano et al., 1991). Therefore, $P$. volans orii does not appear dependent on woodpeckers for the excavation of nest cavities.

In Russia, $P$. volans preferentially uses smaller cavities to avoid predators (Airapetyants \& Fokin, 2003). Loeb (1993) also suggested that G. volans uses cavities with small entrances because they provide greater protection from predators. The longest diameter of cavities used by $P$. volans orii was significantly smaller than that of unused ones (Tab. 2), suggesting that $P$. volans orii may also select cavities with smaller entrances.

Cavities of $G$. volans were located at an average height of $4.57 \mathrm{~m}$ above the ground in Michigan and Massachusetts (Muul, 1968) and $6.36 \mathrm{~m}$ in Maryland (Bendel \& Gates, 1987). Glaucomys sabrinus preferentially used artificial nest boxes set further above the ground (Harestad, 1990). In Estonia, cavities of $P$. volans averaged $6.6 \mathrm{~m}$ above the ground (Timm \& Kiristaja, 2002). Pteromys volans orii may also prefer to cavities further from the ground, but we did not examine cavities over $4 \mathrm{~m}$. Further study on nest cavity utility of $P$. volans orii should include analysis of cavity height.

ACKNOWLEDGEMENTS. We are grateful to Y. Asari, C. Tanaka, M. Noda, R. Haraguchi, M. Matsuhashi, K. Akashi, S. Satoh, N. Machida, A. Yoshioka, and I. Izumi, for their technical assistance. We thank Y. Hashimoto, H. Yanagawa, and Y. Konno for their critical comments and C. L. Bridgman for her critical reading of the manuscript.

\section{References}

Abe H., Ishii N., Itoo T., Kaneko Y., Maeda K., Miura S. \& Yoneda M. 2005. A Guide to the Mammals of Japan. Kanagawa: Tokai University Press. 207 pp.

Airapetyants A.E. \& Fokin I.M. 2003. Biology of European flying squirrel Pteromys volans L. (Rodentia: Pteromyidae) in the North-West of Russia // Russian Journal of Theriology. Vol.2. P.105-113.

Bakker V.J. \& Hastings K. 2002. Den trees used by northern flying squirrels (Glaucomys sabrinus) in southeastern Alaska // Canadian Journal of Zoology. Vol.80. P.16231633.

Bendel P.R. \& Gates J.E. 1987. Home range and microhabitat partitioning of the southern flying squirrel (Glaucomys volans) // Journal of Mammalogy. Vol.68. P.243-255.

Cotton C.L. \& Parker K.L. 2000. Winter habitat and nest trees used by northern flying squirrels in sub-boreal forests // Journal of Mammalogy. Vol.81. P.1071-1086.

Hanski I.K., Mönkkönen M., Reunanen P. \& Stevens P. 2000a. Ecology of the Siberian flying squirrel (Pteromys volans) in Finland // Goldingay R.L. \& Scheibe J.S. (eds.). Biology of Gliding Mammals. Fürth: Filander Verlag. P.67-86.

Hanski I.K., Stevens P.C., Ihalempiä P. \& Selonen V. 2000 b. Home-range size, movements, and nest-site use in the Siberian flying squirrel, Pteromys volans // Journal of Mammalogy. Vol.81. P.798-809.

Harestad A.S. 1990. Nest site selection by northern flying squirrels and Dauglus squirrels // Northwestern Naturalist. Vol.71. P.43-45.

Holloway G.L. \& Malcolm J.R. 2007. Nest-tree use by northern and southern flying squirrels in central Ontario // Journal of Mammalogy. Vol.88. P.226-233.

Horikawa Y. 1972. Atlas of the Japanese Flora. Tokyo: Gakken Holdings Corporation Limited. 
Loeb S.C. 1993. Use and selection of red-cockaded woodpecker cavities by southern flying squirrels // The Journal of Wildlife Management. Vol.57. P.329-335.

Martin K., Aitken K.E.H. \& Wiebe. K.L. 2004. Nests sites and nest webs for cavity-nesting communities in interior British Columbia, Canada: nest characteristics and niche partitioning // The Condor. Vol.106. P.5-19.

Masuda Y. 2003. Notes on nesting trees of the giant flying squirrel (Pteromys volans orii) // Bulletin of the Shiretoko Museum. Vol.24. P.67-70 [in Japanese].

McComb W. \& Lindenmayer D. 1999. Dying, dead, and down trees // Hunter Jr. M.L. (ed.). Maintaining Biodiversity in Forest Ecosystems. Cambridge: Cambridge University Press. P.335-372.

Menzel J.M., Ford W.M., Edward J.W. \& Menzel M.A. 2004. Nest tree use by endangered Virginia northern flying squirrel in the central Appalachian mountains // The American Midland Naturalist. Vol.151. P.355-368.

Meyer M.D., Kelt D.A. \& North M.P. 2005. Nest trees of northern flying squirrels in the Sierra Nevada // Journal of Mammalogy. Vol.86. P.275-280.

Muul I. 1968. Behavioral and physiological influences on the distribution of the flying squirrel, Glaucomys volans // Miscellaneous Publications Museum Zoology University of Michigan. Vol.134. P.1-66.

Nakano S., Hino T., Natsume S. Hayashida M., Inaba Y. \& Okuda A. 1991. Notes on nesting trees of Japanese flying squirrel, Pteromys volans orii, in Hokkaido during winter // Bulletin of the College Experiment Forests, Hokkaido University. Vol.48. P.183-190 [in Japanese].
Nowak R.M. 1991. Walker's Mammals of the World. Vol.1, 5th edn. Baltimore and London: Johns Hopkins University Press.

Okitsu S. 2002. Ecology of Boreal Vegetation. Tokyo: Kokon Shoin Limited. 212 pp [in Japanese].

Parks C.G. \& Shaw D.C. 1996. Death and decay: a vital part of living canopies // Northwest Science. Vol.70. P.4653.

Satake Y. 1989. Abies sachalinensis // Satake Y., Hara H., Watari S., Tominari T. (eds.). Wild Flowers of Japan: Woody Plants. Tokyo: Heibonsha Limited. P.10 [in Japanese].

Tatewaki M. 1958. Forest ecology of the islands of the north Pacific ocean. // Journal of the Faculty of Agriculture Hokkaido University. Vol.50. P.371-484.

Taulman J.F. 1999. Selection of nest trees by southern flying squirrel (Sciuridae: Glaucomys volans) in Arkansas // Journal of Zoology. Vol. 248. P.369-377.

Timm U. \& Kiristaja P. 2002. The Siberian flying squirrel (Pteromys volans L.) in Estonia // Acta Zoologica Lituanica. Vol.12. P.433-436.

Wilson D.E. \& Reeder D.M. 2005. Mammal Species of the World: A Taxonomic and Geographic Reference. 3rd. edn. Baltimore: The Johns Hopkins University Press. $2142 \mathrm{pp}$.

Yamamoto H., Nitami T. \& Kisanuki H. 1995. Stand structure of mixed-species stands (I) Relation of species composition and topographic factors // Journal of the Japanese Forestry Society. Vol.77. P.47-54 [in Japanese with English abstract]. 